\title{
elsevier_JCBM_7851
}

\section{Mineralogical evolution of salt over nine years, after removal of efflorescence and saline crusts from Elche's Old Bridge (Spain)}

Salvador Ordóñez ${ }^{\mathrm{a}, \mathrm{b}, *}$

salvador@ua.es

Ángel La Igesia ${ }^{\mathrm{b}, \mathrm{c}}$

iglesia@geo.ucm.es

Miguel Louis $s^{\mathrm{b}, \mathrm{d}}$

miguel.louis@ua.es

$\mathrm{M}^{\mathrm{a}}$ Ángeles García-del-Cura $\mathrm{b}^{\mathrm{b}} \mathrm{c}$

agcura@geo.ucm.es

aDepartamento de Ciencias de la Tierra y del Medio Ambiente, Universidad de Alicante, San Vicente del Raspeig, 03690, Spain

bLaboratorio de Petrologia Aplicada, Unidad Asociada Universidad de Alicante-CSIC, San Vicente del Raspeig, 03690 Alicante, Spain

IInstituto de Geociencias (IGEO, CSIC, UCM), Facultad de Geologia, c/ José Antonio Novais, 12, 28040 Madrid, Spain

dDepartamento de Construcciones Arquitectónicas, Universidad de Alicante, San Vicente del Raspeig, 03690, Spain

*Corresponding author at: Departamento de Ciencias de la Tierra y del Medio Ambiente, Universidad de Alicante, San Vicente del Raspeig, 03690, Spain.

\section{Abstract}

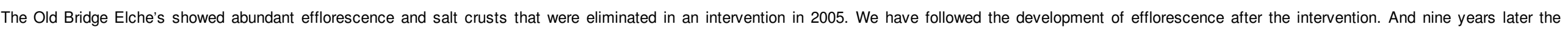
efflorescence mineralogy was quite similar to the mineralogy of the pre-restoration efflorescence.

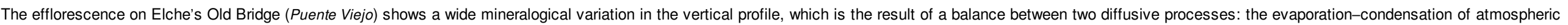

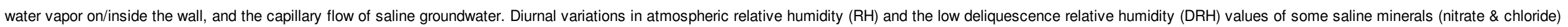
play an important role in the vertical distribution of minerals.

The mineral composition of efflorescence and saline crusts prior to cleaning the monument was similar to that identified nine years later.

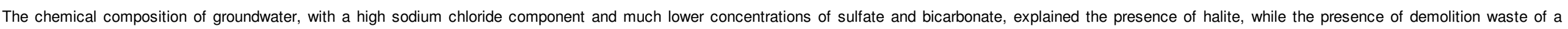

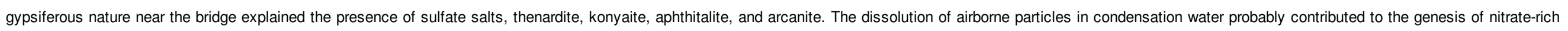
minerals such as nitratine, darapskite, and especially humberstonite.

Keywords: Efflorescences; Salt damage stones; Capillary water; Condensation water; MDRH (mutual deliquescence relative humidity); DRH; RH; Single salts; Double salts; Humberstonite

\section{Introduction}

\subsection{Elche's Old Bridge}

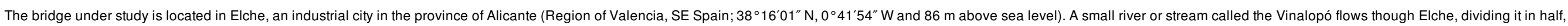
and the Old Bridge (Puente Viejo, also known as the Puente Santa Teresa) is one of the ten bridges that unite both parts of the city. 


\section{elsevier_JCBM_7851}

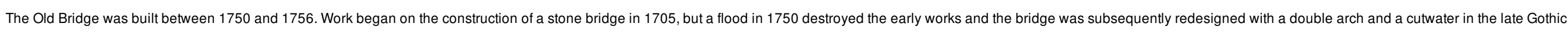

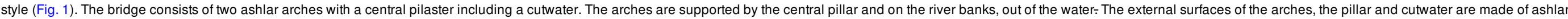

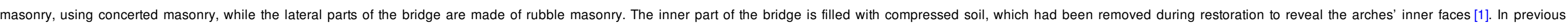
interventions, hygroconvectors had been placed at some points to eliminate possible humidity in the stonemasonry.

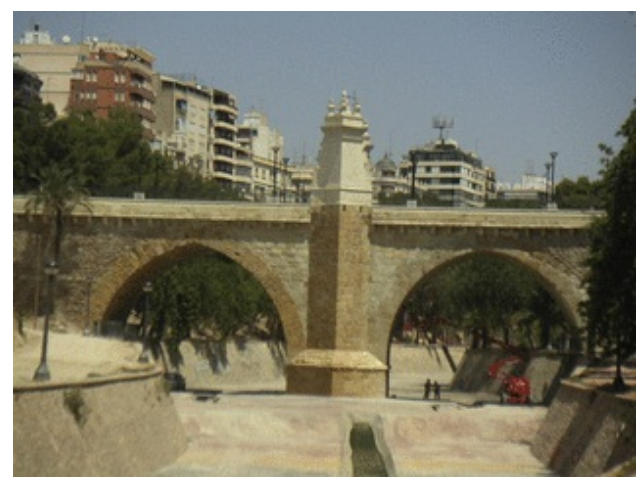

Fig. 1 General view of Elche' Old Bridge, facade N, after restoration (2006).

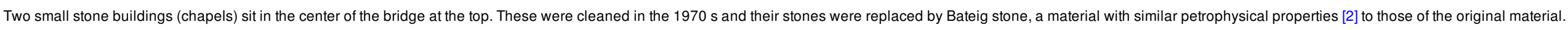

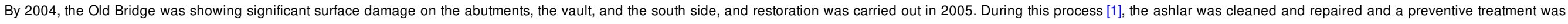

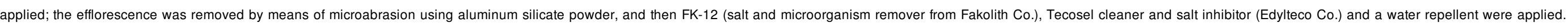

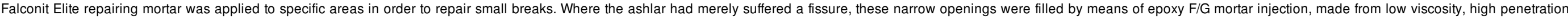

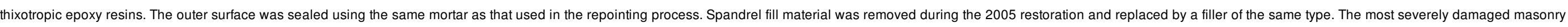

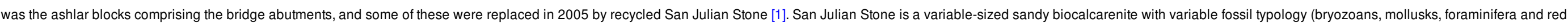
algae) that is quarried in Alicante and has been used in numerous constructions in this town. The properties of this stone vary according to its stratigraphic position.

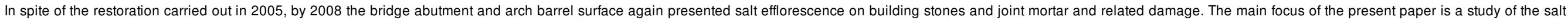
deposits formed on the south side of the bridge (asterisk in Fig. 2A). 


\section{elsevier_JCBM_7851}

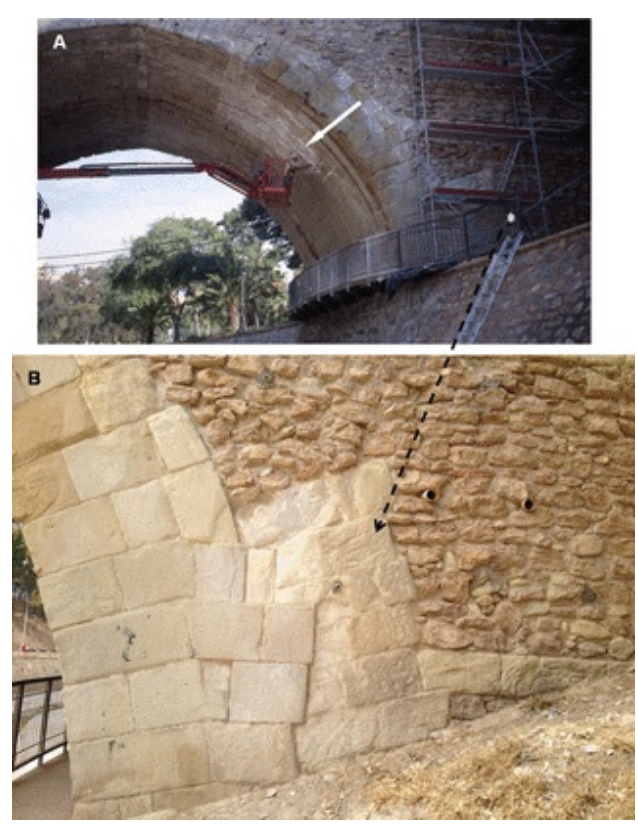

Fig. 2 South side of the bridgel A. Cleaning and sampling of salt vault efflorescence (arrow) (2005). Asterisk shows the preferred study area in this paper. B. View of sampled abutment of the bridge at 2008.

\subsection{Climatic environment}

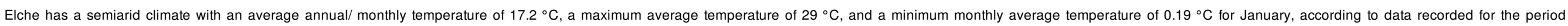
1999-2014 at the Elx station of the Agro-climatic Information System for Irrigation http://eportal.magrama.gob.es/websiar/.

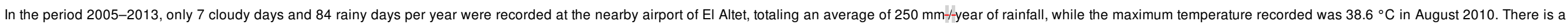

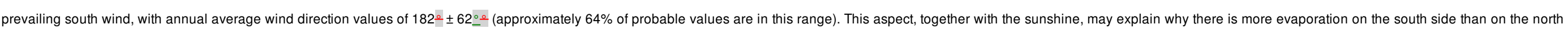
wall of the Old Bridge.

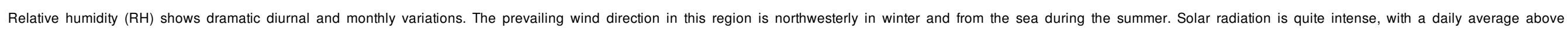

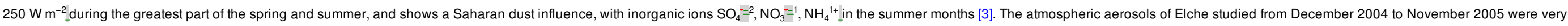

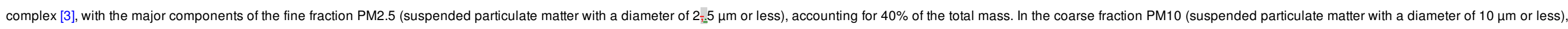
nitrate (as $\mathrm{NaNO}_{3}$ and $\left.\mathrm{Ca}\left(\mathrm{NO}_{3}\right)_{2}\right)$, together with crustal $\left(\mathrm{CaCO}_{3}\right)$ and marine species $(\mathrm{NaCl})$ accounted for almost $50 \%$ of the total mass.

\subsection{Objectives}

The main objectives of this paper are;

a) To describe the evolution over nine years of the mineralogy and textures of salt deposits formed on a monument restored in 2005. Nine years was the time when the efflorescence developed after the intervention reached the composition pre-intervention.

b) To compare post-restoration salts in efflorescence and saline crusts with pre-intervention salts.

c) To analyze the role of capillary water, infittration water and moisture condensation waters in the genesis of efflorescence.

d) To propose a model to explain the origin of saline solutions leading to efflorescence, considering the chemical composition of capillary and seepage water, and also the nature of airborne particles.

e) The final objective of the paper, would provide information about the evolution of the mineralogy of efflorescence for future removal of salt crusts projects. 


\section{elsevier_JCBM_7851}

\section{Materials and methods}

\subsection{Materials}

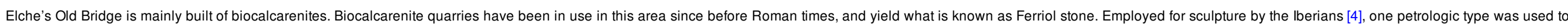
sculpt the "Dama" of Elche, an emblematic Hellenistic Iberian sculpture dated to the fourth of fifth 5 th century B-CE [5].

Some stones in the Elche bridge show the petrographic and aesthetic characteristics of some Ferriol stones; the stones of the lower part of the stratigraphic series of the area in which these quarries are located.

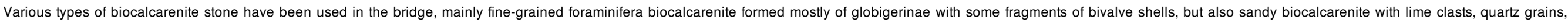

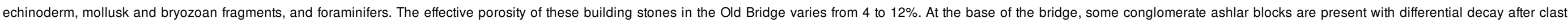
lithology [1].

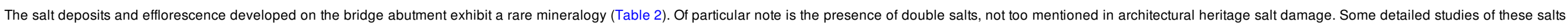
refer to research on Andean salt flats and deposition of aerosol and dust from ventilation air and evaporation of groundwater and seeping into potential geologic repository for nuclear waste.

Table 1 Statistical parameters for ion concentrations in PM2.5 and in PM10 samples, for the period December 2004 to November 2005. After Nicolas et al. [3].

\begin{tabular}{|c|c|c|c|c|c|c|c|c|c|c|}
\hline & \multicolumn{5}{|c|}{$\mathrm{PM} 2.5\left(\mu \mathrm{g} \mathrm{m}^{-3}\right)$} & \multicolumn{5}{|c|}{$\mathrm{PM} 10\left(\mu \mathrm{g} \mathrm{m}^{-3}\right)$} \\
\hline & $\%>$ LD (detection limit) & Mean & SD (standard deviation) & Min. & Max. & $\%>$ LD & Mean & SD & Min. & Max. \\
\hline PM & & 15.4 & 9 & 3.6 & 54.6 & & 34.3 & 15.5 & 9.3 & 73.8 \\
\hline $\mathrm{Cl}^{-}$ & 61 & 0.18 & 0.22 & 0.04 & 1.13 & 100 & 0.6 & 0.5 & 0.06 & 2.27 \\
\hline $\mathrm{NO}_{3}^{-}$ & 100 & 1.37 & 2.21 & 0.1 & 15.5 & 100 & 3.76 & 2.99 & 0.34 & 21.67 \\
\hline $\mathrm{nmSO}_{4}{ }^{2-}$ & 100 & 3.79 & 2.92 & 0.37 & 15.82 & 100 & 4.36 & 3.09 & 0.58 & 16.61 \\
\hline $\mathrm{Na}^{+}$ & 79 & 0.27 & 0.11 & 0.13 & 0.54 & 100 & 0.99 & 0.72 & 0.13 & 3.32 \\
\hline $\mathrm{Ca}^{2+}$ & 16 & 0.36 & 0.16 & 0.23 & 0.85 & 100 & 2.29 & 0.98 & 0.3 & 4.67 \\
\hline $\mathrm{Mg}^{2+}$ & 92 & 0.02 & 0.01 & 0.01 & 0.11 & 100 & 0.16 & 0.1 & 0.02 & 0.46 \\
\hline $\mathrm{K}^{+}$ & 68 & 0.21 & 0.16 & 0.07 & 1.27 & 100 & 0.28 & 0.26 & 0.07 & 2.09 \\
\hline
\end{tabular}

Table 2 Minerals cited in the text and their chemical formulas.

\begin{tabular}{|c|c|}
\hline Halite & $\mathrm{NaCl}$ \\
\hline Thenardite & $\mathrm{Na}_{2} \mathrm{SO}_{4}$ \\
\hline Mirabilite & $\mathrm{Na}_{2} \mathrm{SO}_{4} \cdot 10 \mathrm{H}_{2} \mathrm{O}$ \\
\hline Konyaite & $\mathrm{Na}_{2} \mathrm{Mg}\left(\mathrm{SO}_{4}\right)_{2} \cdot 5 \mathrm{H}_{2} \mathrm{O}$ \\
\hline Nitratine & $\mathrm{NaNO}_{3}$ \\
\hline Humberstonite & $\mathrm{K}_{3} \mathrm{Na}_{7} \mathrm{Mg}_{2}\left(\mathrm{SO}_{4}\right)_{6}\left(\mathrm{NO}_{3}\right)_{2} \cdot 6 \mathrm{H}_{2} \mathrm{O}$ \\
\hline Arcanite & $\mathrm{K}_{2} \mathrm{SO}_{4}$ \\
\hline Aphtitalite & $(\mathrm{K}, \mathrm{Na})_{3} \mathrm{Na}\left(\mathrm{SO}_{4}\right)_{2}$ \\
\hline
\end{tabular}




\section{elsevier_JCBM_7851}

Sylvite

\subsection{Methods}

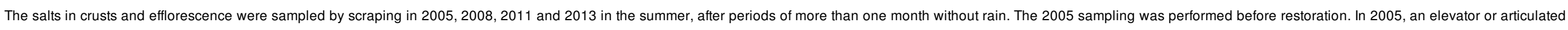

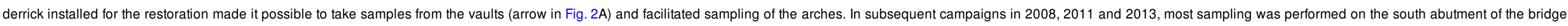
(Fig. 2B) which is where most of the efflorescence had formed.

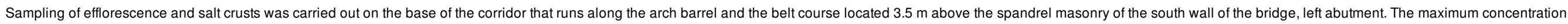

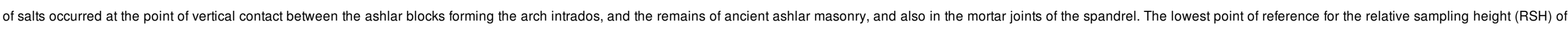
saline efflorescence and crusts was the corridor that runs along the abutment.

Saline soils of the left bridge abutment foundation have been sampled using a set of nozzles $1 \mathrm{~cm}$ in diameter, which could be obtained $20 \mathrm{~cm}$ thick cores, and were used to determine the soluble ions in the soil foundation.

The mineralogy of the salts found in the stones was determined by XRD and SEM with EDS. Chemical analysis of soils in the area was performed by XRF and ion chromatography

\subsubsection{XRD}

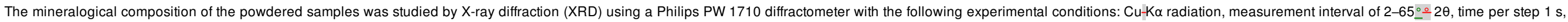

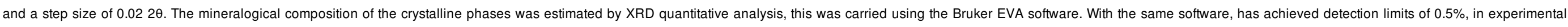
mixtures of halite- -thenardite, based on these results can be considered acceptable $1 \%$ values presented in this paper

\subsubsection{SEM}

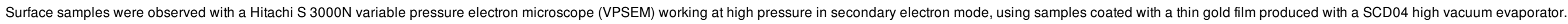
Uncoated surfaces were studied in low pressure backscattered electron mode using an EDS Bruker X Flash 3001 model in order to examine the compositional heterogeneity of the samples.

\subsubsection{XRF}

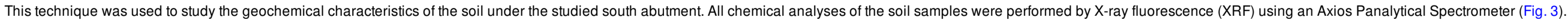




\section{elsevier_JCBM_7851}
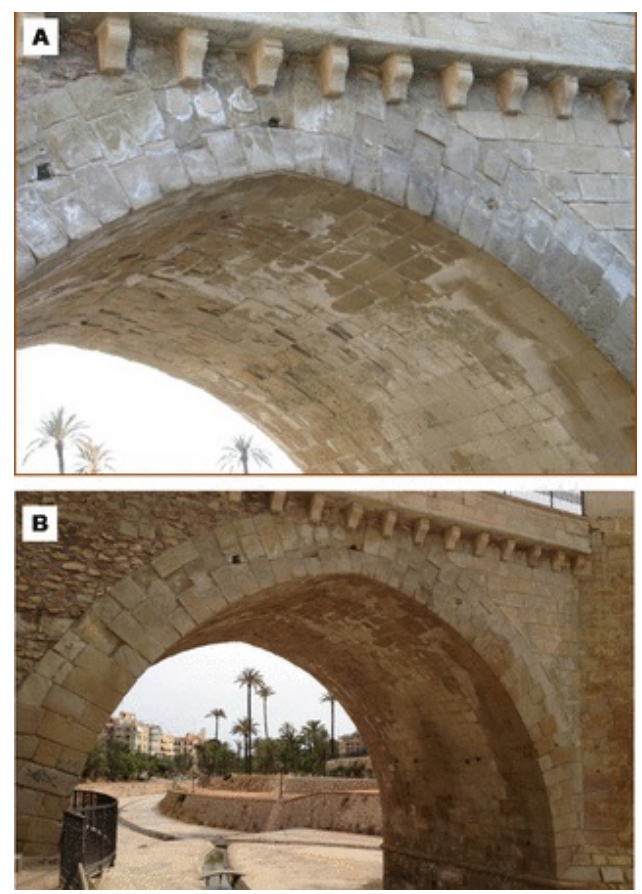

Fig. 3 Efflorescence on the $\mathrm{N}$ face of the arch and on the vaultt_ A. At 2008, B⿺ North face of the arch at 2013. Outer surface is free from salts, but flaking and contour scaling are evident.

\subsubsection{Ion chromatography}

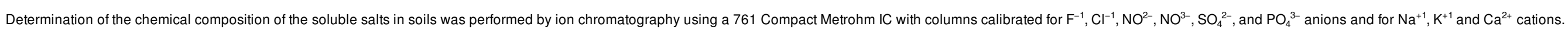

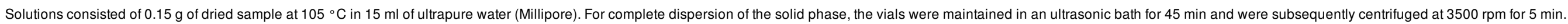

\section{Results}

The principal damage observed, described after Fitzner \& Heinrichs (2004) [6], was as follows:

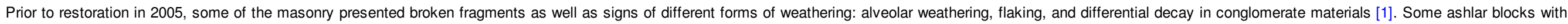

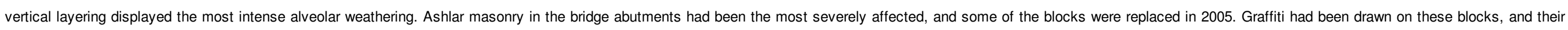
color had changed.

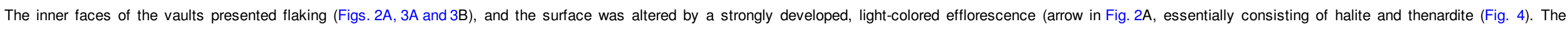

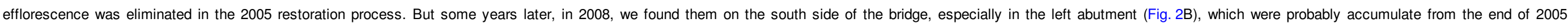
restoration. 


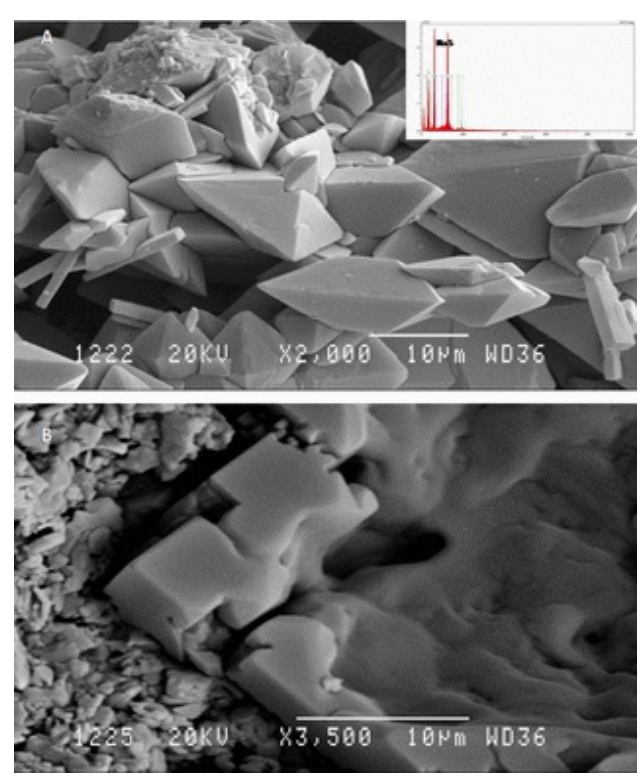

Fig. 4 SEM photomicrographs in se mode. A) Thenardite with EDS analysis_ B) Halite with dissolution features.

\subsection{Efflorescence and saline crusts: mineralogical composition}

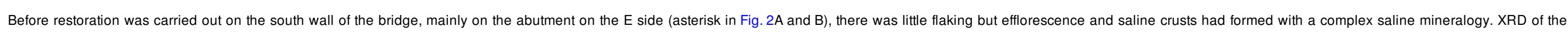
samples revealed the following crystalline phases: halite, thenardite, mirabilite, arcanite, darapskite, konyaite, humberstonite, nitratine, aphthitalite, and sylvite.

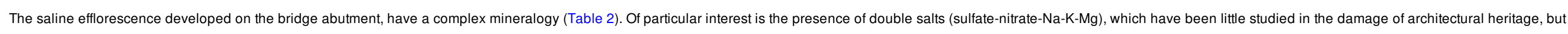

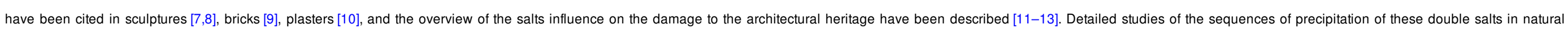
environments, can be observed in the Andean salt flats, as pointed out later.

\subsection{The most relevant aspects of some of the most singular double salts found in efflorescence}

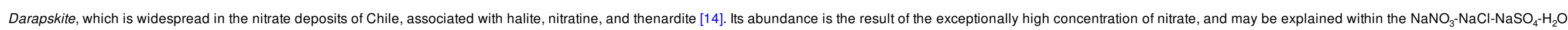

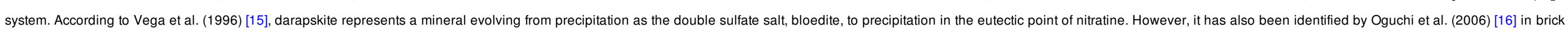
monuments. This mineral was identified in the efflorescence described here in significant amounts in the 2013 sampling.

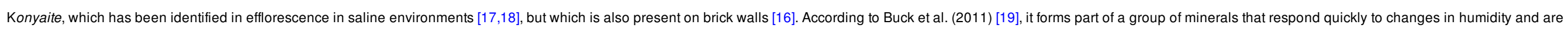
hydrous / anhydrous.

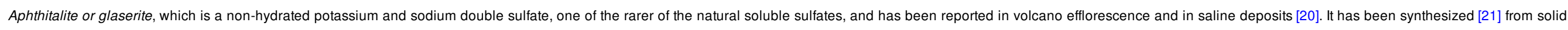
bittern treated with $\mathrm{CIK}$ in the $2 \mathrm{CINa}-\mathrm{K}_{2} \mathrm{SO}_{4}-2 \mathrm{CIK}$ system. They have also been cited in decay processes in stone monuments [22]

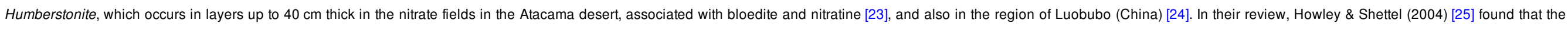

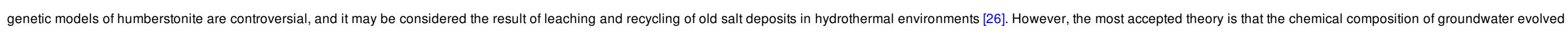

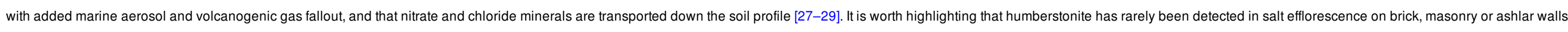
[30]. 


\section{elsevier_JCBM_7851}

\subsection{Efflorescence and saline crusts: mineralogical composition}

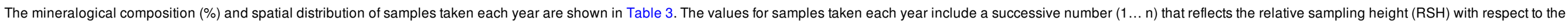
base of the corridor that runs along the arch barrel. The height difference between two successive samples varied between 55 and $50 \mathrm{~cm}$.

Table 3 Data and values of the arithmetic mean, standard deviation, for salt content (\%) of samples taken from 2005 to 2013. RSH = relative sampling height.

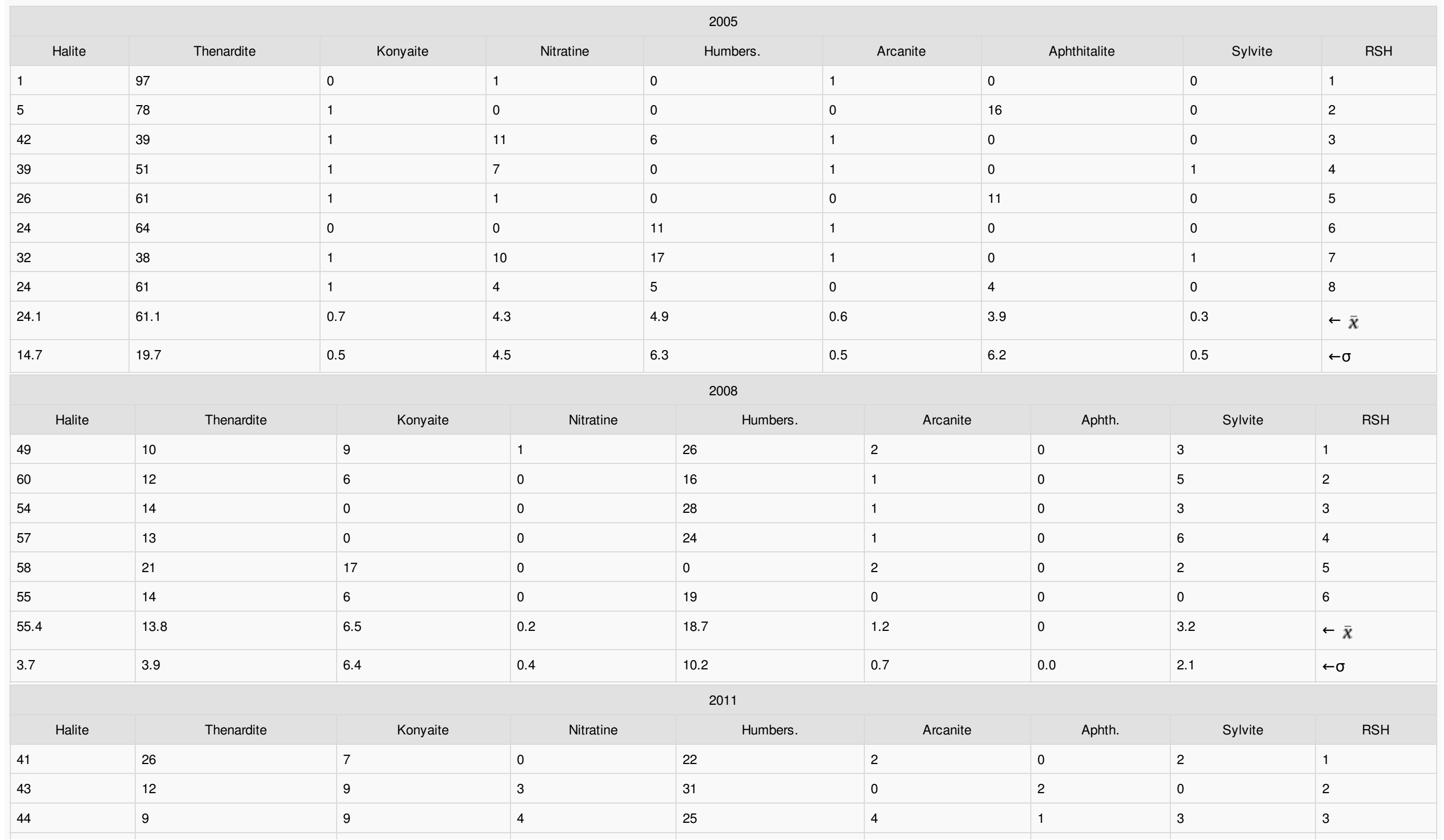




\section{elsevier_JCBM_7851}

\begin{tabular}{|c|c|c|c|c|c|c|c|c|}
\hline 52 & 8 & 17 & 6 & 12 & 4 & 0 & 3 & 4 \\
\hline 51 & 9 & 10 & 4 & 23 & 0 & 1 & 1 & 5 \\
\hline 68 & 7 & 0 & 3 & 19 & 0 & 1 & 1 & 6 \\
\hline 77 & 18 & 0 & 1 & 0 & 0 & 1 & 3 & 7 \\
\hline 77 & 19 & 0 & 0 & 0 & 0 & 0 & 4 & 8 \\
\hline 56.6 & 13.7 & 6.6 & 2.8 & 16.5 & 1.3 & 0.8 & 2.1 & $\leftarrow \bar{x}$ \\
\hline 15.1 & 6.8 & 6.2 & 2.2 & 11.4 & 1.9 & 0.7 & 1.3 & $\leftarrow \sigma$ \\
\hline
\end{tabular}

2013

\begin{tabular}{|c|c|c|c|c|c|c|c|c|c|}
\hline Halite & Thenardite & Konyaite & Nitratine & Humbers. & Arcanite & Aphth. & Sylvite & Darapskite & RSH \\
\hline 8 & 61 & 17 & 0 & 0 & 0 & 12 & 2 & 0 & 1 \\
\hline 8 & 69 & 0 & 0 & 9 & 0 & 6 & 0 & 8 & 2 \\
\hline 8 & 66 & 11 & 0 & 5 & 0 & 5 & 0 & 5 & 3 \\
\hline 60 & 14 & 17 & 0 & 5 & 0 & 4 & 0 & 0 & 4 \\
\hline 61 & 14 & 8 & 0 & 11 & 0 & 1 & 0 & 5 & 5 \\
\hline 70 & 16 & 0 & 0 & 10 & 0 & 1 & 0 & 3 & 6 \\
\hline 58 & 22 & 3 & 0 & 14 & 0 & 0 & 0 & 3 & 7 \\
\hline 59 & 17 & 6 & 0 & 18 & 0 & 0 & 0 & 0 & 8 \\
\hline 41.5 & 34.9 & 7.8 & 0 & 9.0 & 0 & 3.6 & 0.3 & 3.0 & $\leftarrow \bar{x}$ \\
\hline 28.0 & 25.4 & 6.8 & 0 & 5.7 & 0 & 4.1 & 0.7 & 2.9 & $\leftarrow \sigma$ \\
\hline
\end{tabular}

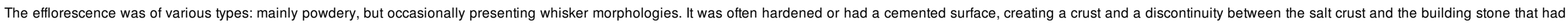
been favored by erosion, mainly through flaking.

In 2011, six years after the cleaning process [1] described in the introduction salts appeared as crusts of the order of $10 \mu$ thick and as sub-efflorescence located 20-30 $\mu \mathrm{m}$ away from the surface.

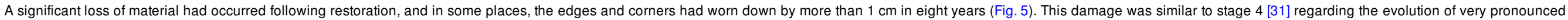
alveoli; however, in this case it was related to granular disintegration into sand. In some corners of the south side, massive loss of material was observed, generally associated with concave erosion surfaces (arrows). 


\section{elsevier_JCBM_7851}

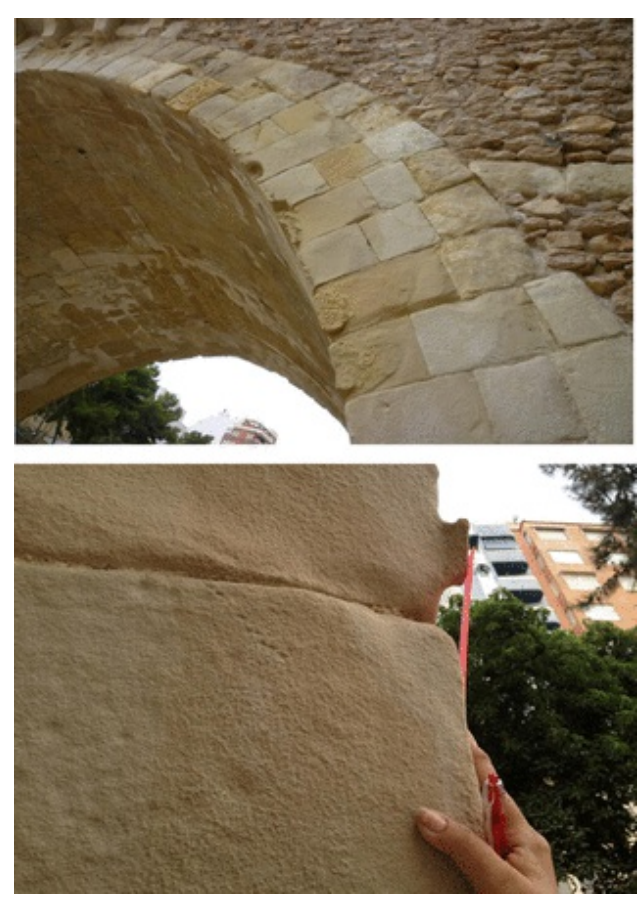

Fig. 5 Erosion on the corners of the south wall. July 2013.

\subsection{Salt mineralogy, 2005}

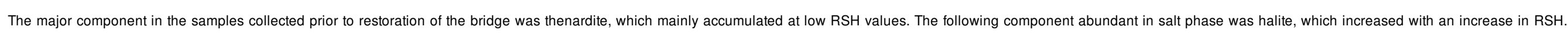

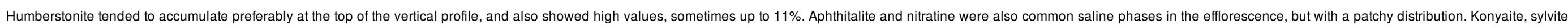
and arcanite showed truly low values, also appearing in a patchy distribution.

\subsection{Salt mineralogy, 2008}

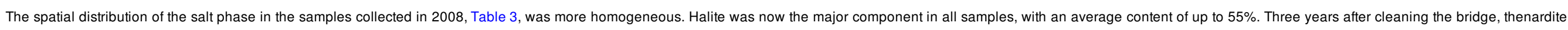

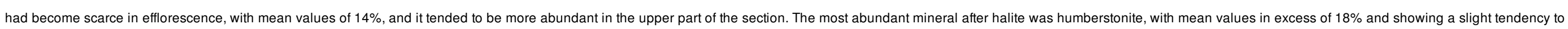
accumulate at the bottom of the profile. Also present were konyaite $(6 \%)$ and sylvite $(4 \%)$, both presenting a patchy distribution.

\subsection{Salt mineralogy, 2011}

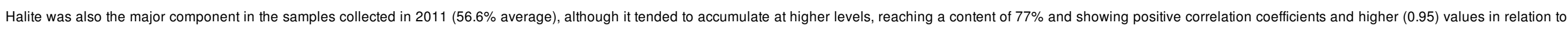

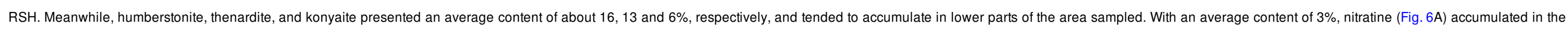
middle levels, while arcanite (Fig. 6B), aphthitalite, and sylvite had an average content of between 1 and $2 \%$ and showed a patchy distribution (Table 3). 


\section{elsevier_JCBM_7851}

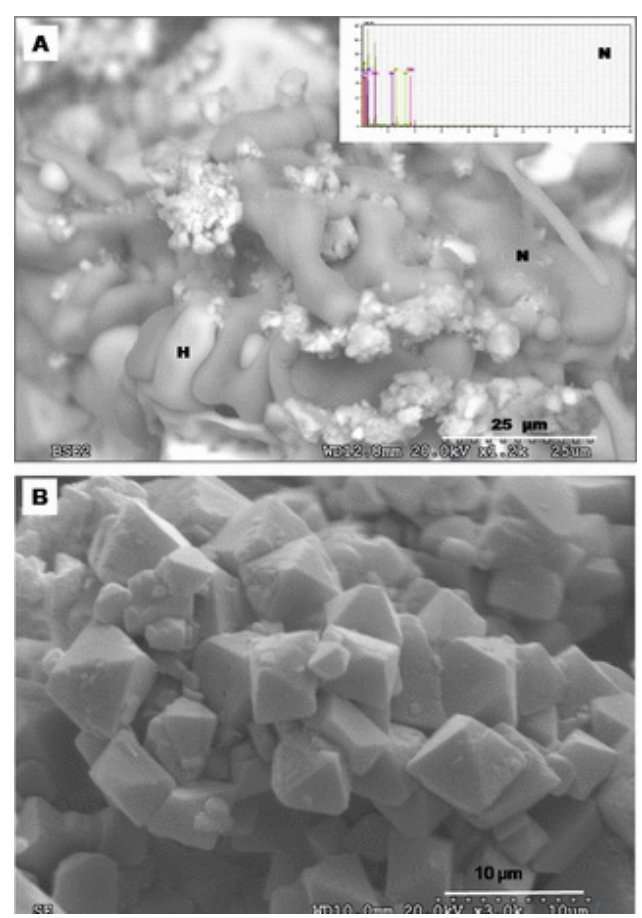

Fig. 6 A. SEM photomicrograph in bse mode of sodium salts and EDS. $H$ halite and $N$ nitratine. B. SEM photomicrograph in se mode of arcanite.

\subsection{Salt mineralogy, 2013}

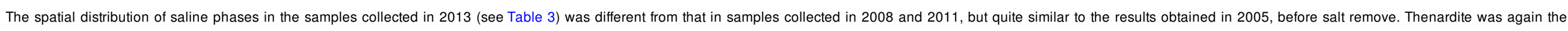

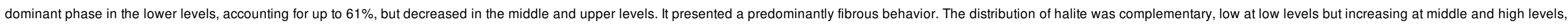

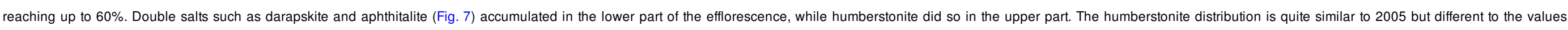
obtained in 2008 and 2011 (Table 3). 


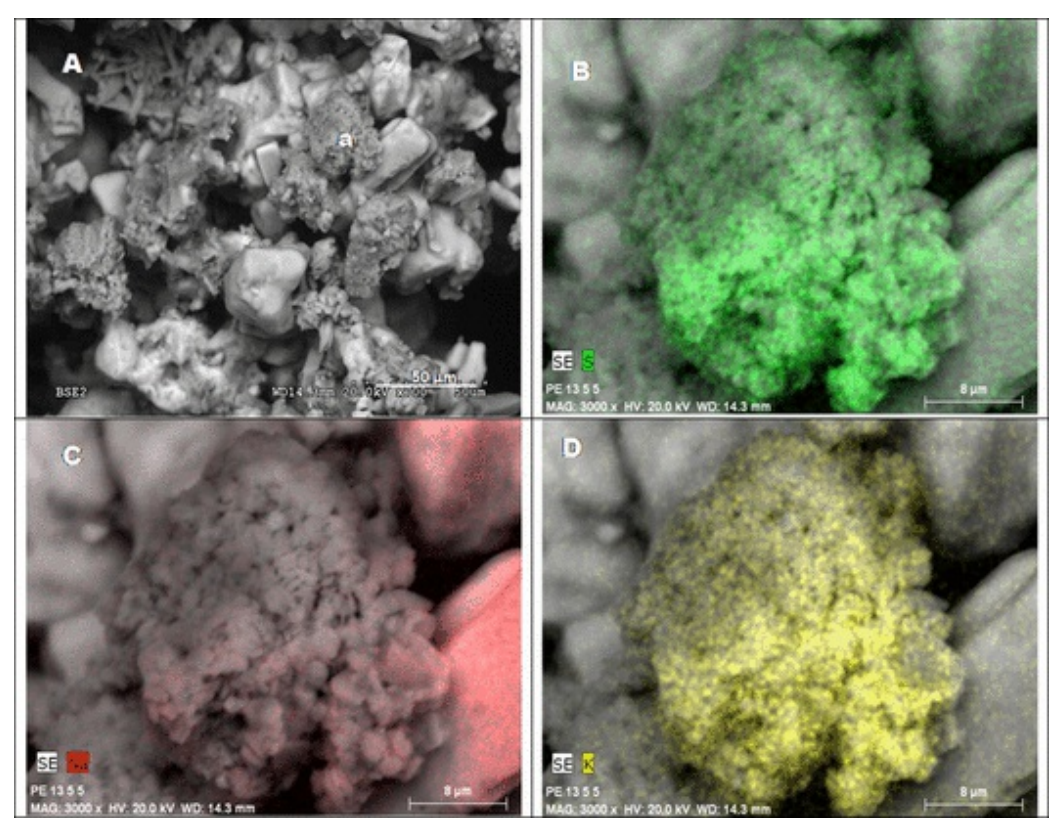

Fig. 7 Aphtitalite. A SEM photomicrograph in se mode (an aphtitalite aggregate) B, C and D some element distribution (B: Sulfur; C: sodium; D potassium).

\subsection{Soluble anions and cations in the soil near the bridge abutment}

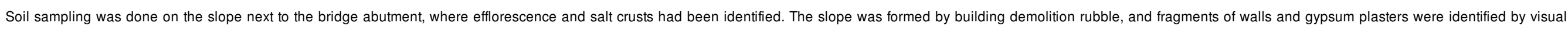

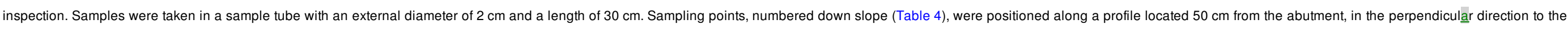

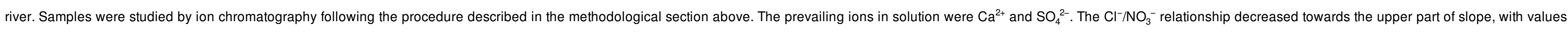
close to 1.6 , implying an increase in nitrates. Meanwhile, $\mathrm{Na}^{+} / \mathrm{K}^{+}$showed no similar trends in variation trends and values ranged from 2.7 to 4.7 (Table 5 ).

Table 4 Data for soluble anions and cations in soils. Samples taken downwards (1-4) on the landfill demolition, located on the left abutment.

\begin{tabular}{|c|c|c|c|c|}
\hline & Sample 1 & Sample 2 & Sample 3 & Sample 4 \\
\hline \multicolumn{5}{|l|}{ Anions (meq/l) } \\
\hline $\mathrm{Cl}^{-}$ & $2,-38$ & $2:-28$ & $2-40$ & $1 ;-43$ \\
\hline $\mathrm{NO}_{3}^{-}$ & $1=49$ & 0,84 & $0=83$ & $0=36$ \\
\hline $\mathrm{SO}_{4}^{2-}$ & $17:-51$ & 17:-14 & $7:-34$ & $20-48$ \\
\hline Eanions (eq.) & $21,-37$ & $20=27$ & $10=56$ & $22-27$ \\
\hline \multicolumn{5}{|l|}{ Cations (meq/l) } \\
\hline $\mathrm{Na}^{+}$ & $3:-15$ & $3:-15$ & $3=80$ & 2,61 \\
\hline $\mathrm{Ca}^{2+}$ & $24-34$ & $19=63$ & $8 \div-73$ & $24=67$ \\
\hline $\mathrm{K}^{+}$ & $0-79$ & $1,-15$ & $0=82$ & $0=67$ \\
\hline
\end{tabular}


Table 5 Monthly variation in [RHmaximun (\%) - RHmínimun (\%)]/RHaverage] referring to the RH value. Data from: "Climatic data for Elche, 2000-2014, from the Elx EEA SIAR meteorological station".

\begin{tabular}{|c|c|c|c|c|}
\hline Month & Maximum RH (\%) & Minimum RH (\%) & Average $\mathrm{RH}(\%)$ & $\Delta \mathrm{RH}$ monthly/RH average \\
\hline 1 & 95.68 & 19.86 & 63.7 & 1.19 \\
\hline 2 & 96.05 & 16.88 & 61.88 & 1.28 \\
\hline 3 & 96.53 & 17.02 & 61.7 & 1.29 \\
\hline 4 & 96.25 & 17.03 & 61.15 & 1.3 \\
\hline 5 & 95.56 & 18.07 & 61.1 & 1.27 \\
\hline 6 & 93.44 & 17 & 59.77 & 1.28 \\
\hline 7 & 93.59 & 16.74 & 63.11 & 1.22 \\
\hline 8 & 93.61 & 17.54 & 64.05 & 1.19 \\
\hline 9 & 94.91 & 19.93 & 66.12 & 1.13 \\
\hline 10 & 96.19 & 21.79 & 68.1 & 1.09 \\
\hline 11 & 96.53 & 22.35 & 63.94 & 1.16 \\
\hline 12 & 96.62 & 23.49 & 64.47 & 1.13 \\
\hline
\end{tabular}

\section{Discussion}

\subsection{Geochemistry and physical chemistry of minerals}

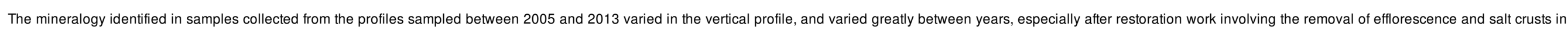

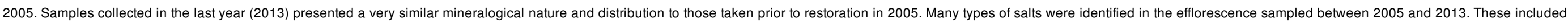

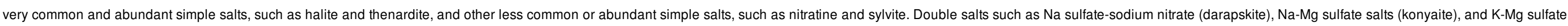
salts (aphthitalite) were also found, together with perhaps the most abundant double salt identified in the efflorescence studied here, also a K-Na-Mg sulfate-nitrate (humberstonite).

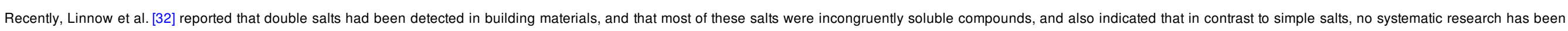

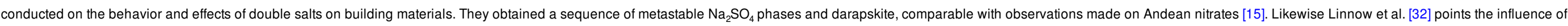
$\mathrm{RH}$ (atmospheric relative humidity) on the nature of the salts $\mathrm{NaNO}_{3}-\mathrm{Na}_{2} \mathrm{SO}_{4}-\mathrm{H}_{2} \mathrm{O}$, and also observed aphthitalite formation when potassium sulfate was added to the previous thermodynamic system [33].

Below, we highlight some of the mineralogical aspects of some of the double salts identified in the efflorescence collected from the left abutment of the bridge at Elche.

\subsection{The physical and physical-chemical processes involved in the genesis of efflorescence and salt crusts}

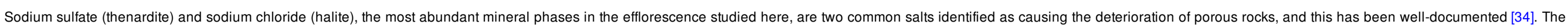

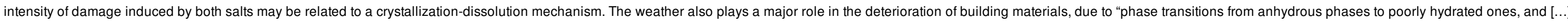

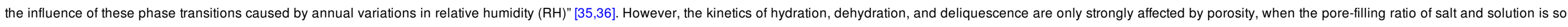

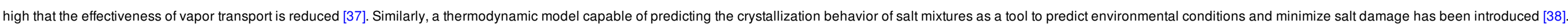

\subsubsection{Imbibition or capillary waters, and solute origin}




\section{elsevier_JCBM_7851}

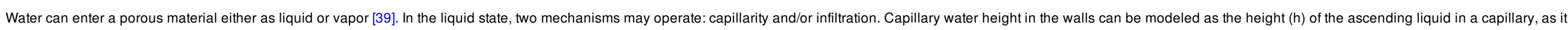
is well know:

$H=\frac{2 S_{L V} \cos \theta}{\rho g r}$

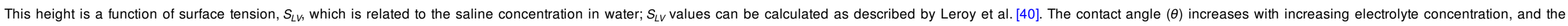

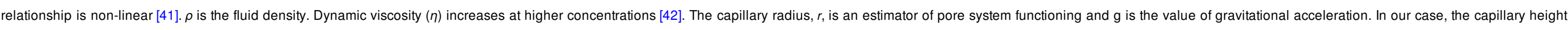

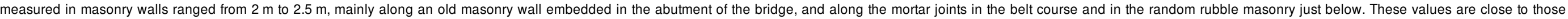
reported by Martínez-Martínez et al. [43].

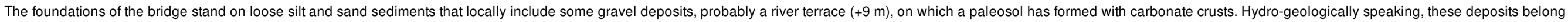

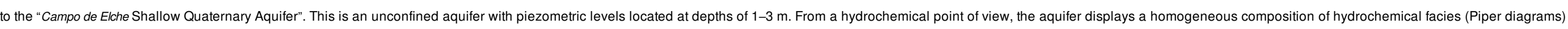
with a high sodium chloride component, much lower concentrations of sulfate and bicarbonate, and high conductivity values sometimes in excess of 10,000 $\mu \mathrm{S} / \mathrm{cm}$ in the central sector [44].

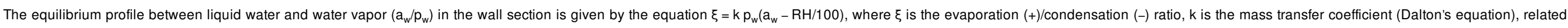

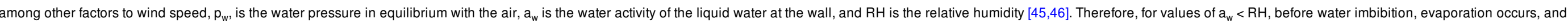

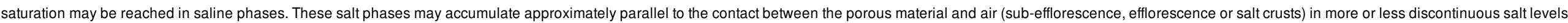

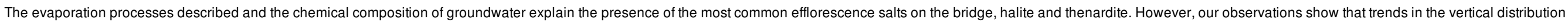

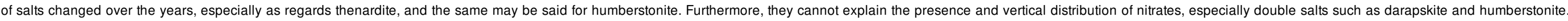

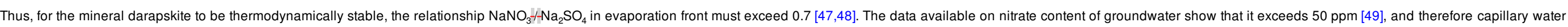
evaporation alone does not explain the salts identified in the salt crusts and efflorescence.

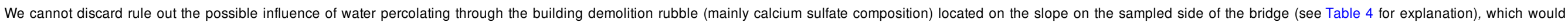

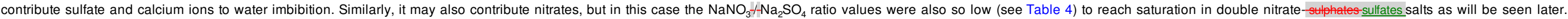

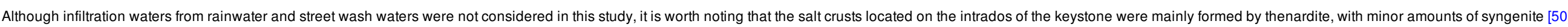

\subsubsection{Water vapor condensation $\left.[(R H / 100)]>a_{w}\right)$ and $P M($ particulate matter in the air)}

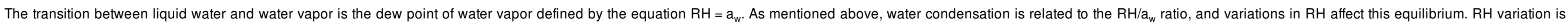

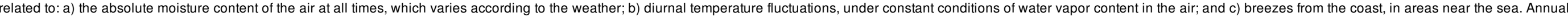

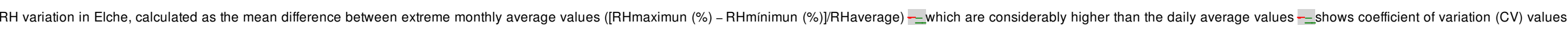
below $6 \%$.

Given the wide variations in the monthly average $\mathrm{RH}$, the absolute value of which differed little from daily average variations, these variations in $\mathrm{RH}$ can be considered a basic factor in daily moisture/dryness cycles in the walls.

Meanwhile, the other factor relationship, $a_{w}$, varies according to:

a) The surface roughness of walls, an effect known as the Lotus Effect and described by Philip [51], this work furnished a quantitative basis for analyzing combine adsorption and capillary condensation on rough surfaces, and is not take in account in this pape

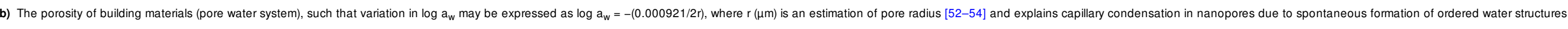
which are energetically favored. Similarly, the effect of grain size can be described, whereby fine grains tend to hold more moisture than coarse ones see [55].

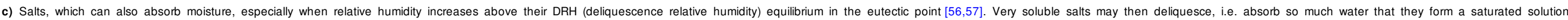

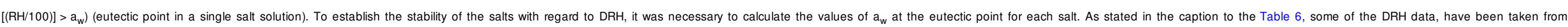

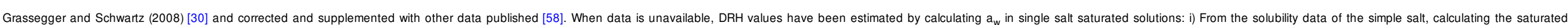




\section{elsevier_JCBM_7851}

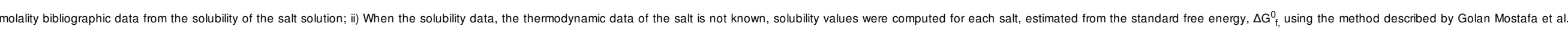

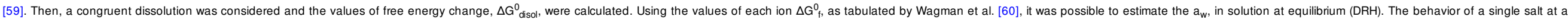
given temperature can be sufficiently characterized by a single value of DRH. If the humidity remains above this RH the salt remains dissolved, however, if it drops below the DRH the salt will crystallize [12] (Table 7).

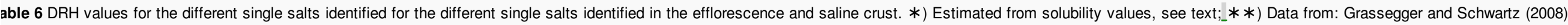
[30], **) corrected and supplemented with other data published [58].

\begin{tabular}{|c|c|}
\hline & DRH (\%) \\
\hline Darapskite & $67.6^{*}$ \\
\hline Nitratine & $74.2^{* *}$ \\
\hline Halite & $75.3 * *$ \\
\hline Humberstonite & $77.8^{*}$ \\
\hline Sylvite & $84.3 * *$ \\
\hline Thenardite & $86.9 * *$ \\
\hline Konyaite & $88.7^{*}$ \\
\hline Aphthitalite & $91.2^{*}$ \\
\hline Arcanite & $97.3 * *$ \\
\hline
\end{tabular}

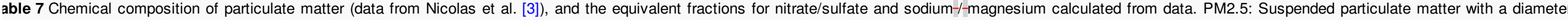
less than $2.5 \mu$. PM10: Suspended particulate matter with a diameter less than $10 \mu \mathrm{m}$.

\begin{tabular}{|c|c|c|c|}
\hline \multicolumn{4}{|c|}{ PM2.5 } \\
\hline & Anions $\left(\mu \mathrm{g} \mathrm{m}^{-3}\right)$ & Mean & SD \\
\hline $\mathrm{Cl}^{-}$ & & 0.18 & 0.22 \\
\hline $\mathrm{NO}_{3}^{-}$ & & 1.37 & 2.21 \\
\hline $\mathrm{NH}_{4}^{+}$ & & 1.63 & 1.4 \\
\hline $\mathrm{SO}_{4}^{2-}$ & & 3.79 & 2.92 \\
\hline$\Sigma N / \Sigma N+S$ & & 0.58 & \\
\hline Cations $\left(\mu \mathrm{g} \mathrm{m}^{-3}\right)$ & & Mean & SD \\
\hline $\mathrm{Na}^{+}$ & & 0.27 & 0.11 \\
\hline $\mathrm{Ca}^{2+}$ & & 0.36 & 0.16 \\
\hline $\mathrm{Mg}^{2+}$ & & 0.02 & 0.01 \\
\hline $\mathrm{K}^{+}$ & & 0.21 & 0.16 \\
\hline
\end{tabular}




\begin{tabular}{|c|c|c|}
\hline $\mathrm{Na}^{+} /\left(\mathrm{Na}^{+}+\mathrm{Mg}^{2+}\right)$ & 0.86 & \\
\hline \multicolumn{3}{|l|}{ PM10 } \\
\hline Anions $\left(\mu \mathrm{g} \mathrm{m}^{-3}\right)$ & Mean & SD \\
\hline $\mathrm{Cl}^{-}$ & 0.60 & 0.5 \\
\hline $\mathrm{NO}_{3}^{-}$ & 3.76 & 2.99 \\
\hline $\mathrm{NH}_{4}^{+}$ & 1.10 & 1.19 \\
\hline $\mathrm{SO}_{4}{ }^{2-}$ & 4.36 & 3.09 \\
\hline$\Sigma N / \Sigma N+S$ & 0.57 & \\
\hline Cations $\left(\mu \mathrm{g} \mathrm{m}^{-3}\right)$ & Mean & SD \\
\hline $\mathrm{Na}^{+}$ & 0.99 & 0.72 \\
\hline $\mathrm{Ca}^{2+}$ & 2.29 & 0.98 \\
\hline $\mathrm{Mg}^{2+}$ & 0.16 & 0.1 \\
\hline $\mathrm{K}^{+}$ & 0.28 & 0.26 \\
\hline $\mathrm{Na}^{+} /\left(\mathrm{Na}^{+}+\mathrm{Mg}^{2+}\right)$ & 0.77 & \\
\hline
\end{tabular}

The results obtained show that the salts with DRH values below that of halite may redissolve almost daily, which can substantially modify the precipitation sequence of salts related to previous salts from water imbibitions or capillaries. Such damage is the result of crystallization pressure, which causes material fatigue due to the high frequency compression-decompression cycles associated with crystallization-dissolution. This frequency can be seen daily in climates such as that of Elche, with strong diurnal variations in RH, lading to salt efflorescence with minerals of lower DRH (deliquescence relative humidity) values. This is probably one of the most important factors in the evolution of saline efflorescence minerals, and in the analysis of the damage to the stone materials induced by salt crystallization-solution processes.

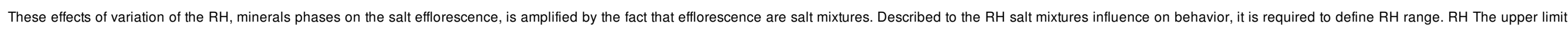

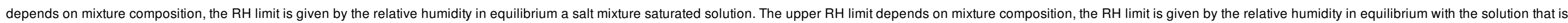
saturated in both solids. This relative humidity is called the mutual DRH (MDRH). "The MDRH is always lower than the DRH of any single salt in the mixture [12,56,57,61,62].

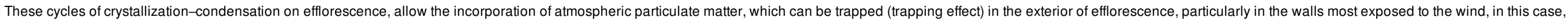
the south wall affected by the prevailing winds.

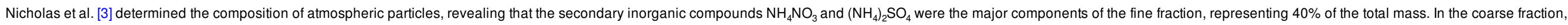

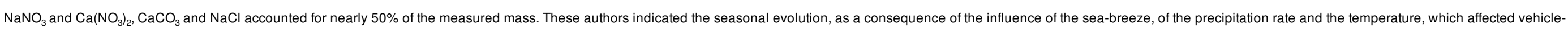

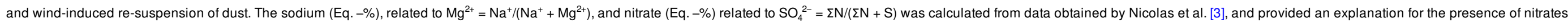
in the efflorescence.

\subsubsection{The genesis of double salts within efflorescence and relative humidity (DRH and MDRH)}

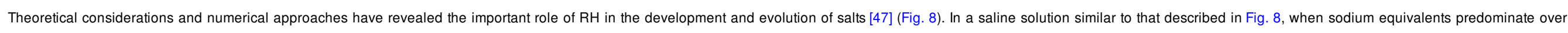

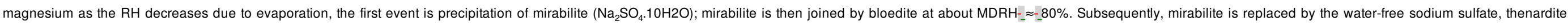

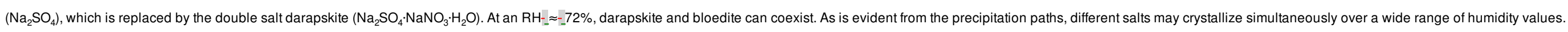




\section{elsevier_JCBM_7851}

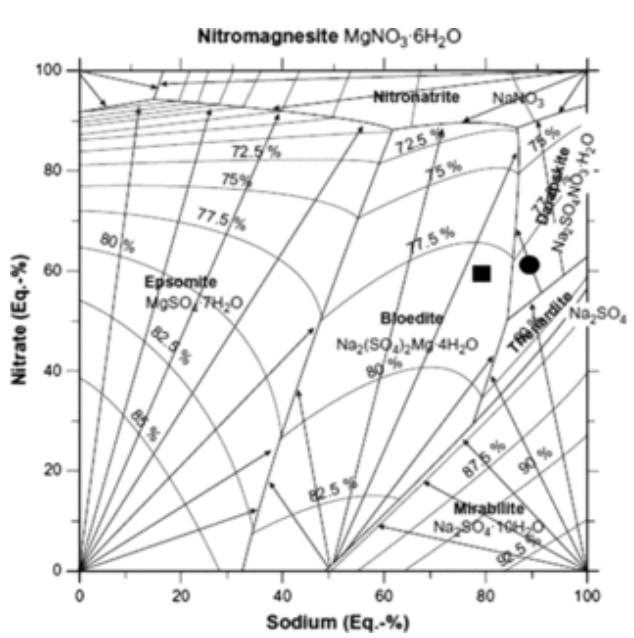

Fig. 8 Projection from RH_(\%) in the $\mathrm{Na}_{-}-\mathrm{Mg}_{-} \mathrm{SO}_{4}-\mathrm{NO}_{3}-\mathrm{H}_{2} \mathrm{O}$ system, phase diagram after Franzen \& Mirwal (2009) [51]. Hairlines represent RH isobars; arrows show evolution path of solution during drying. Graphic symbols used: PM 2.5, circle; PM10, squares.

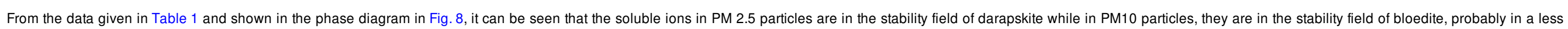

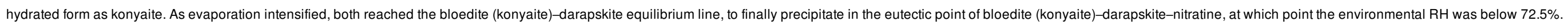

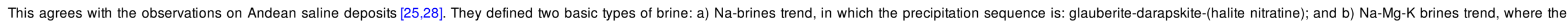

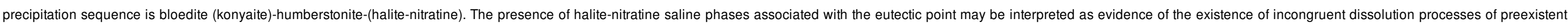

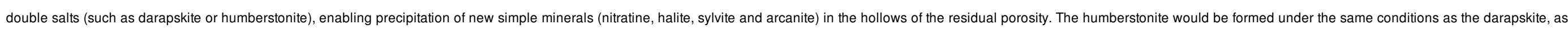

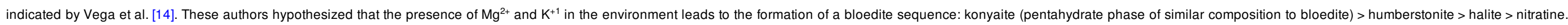

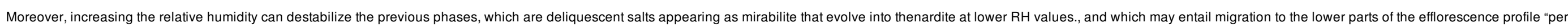

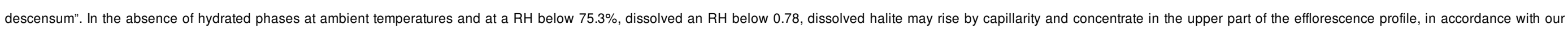
observations on the vertical distribution of minerals. This process is repeated almost daily, due to sudden changes in environmental RH.

\section{Conclusions}

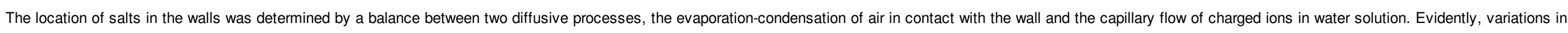

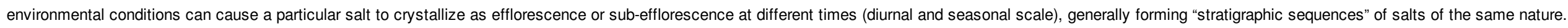

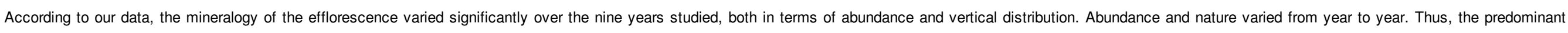

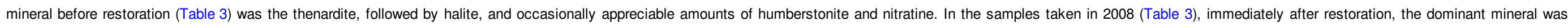

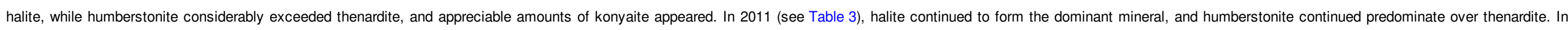
2013 (see Table 3) the predominant mineral was again halite, but there was also a strong presence of thenardite, and significant amounts of humberstonite and konyaite.

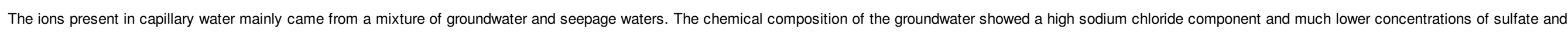

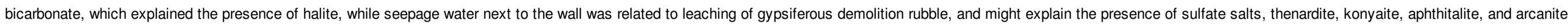

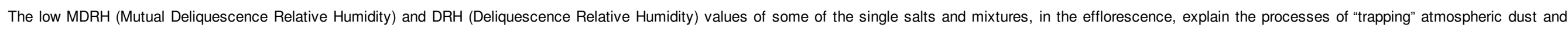

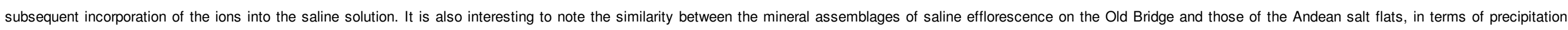
sequences and SEM textures.

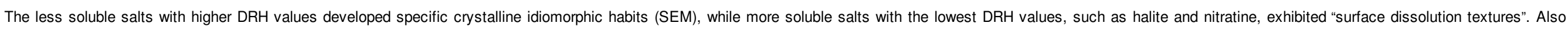




\section{elsevier_JCBM_7851}

notable was the occasional presence of thenardite (XRD) with a fibrous habit (SEM), a pseudomorph from mirabilite.

The salt mineralogy of the efflorescence varied over time, but in general, the present mineralogical composition is similar to that identified prior to cleaning and restoration of the bridge nine years ago.

\section{Final considerations and recommendations}

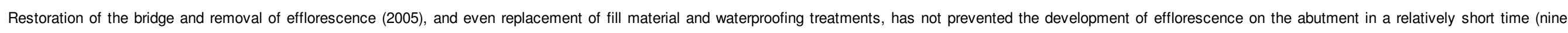

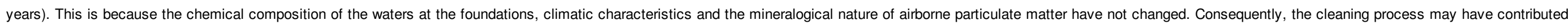

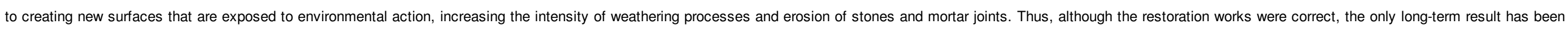
the virtual disappearance of water infiltration efflorescence on the arch barrel.

\section{Acknowledgements}

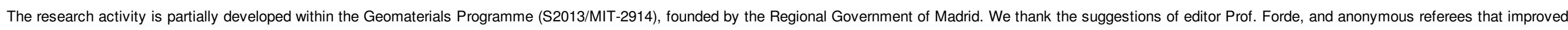
our manuscript.

\section{References}

[1]

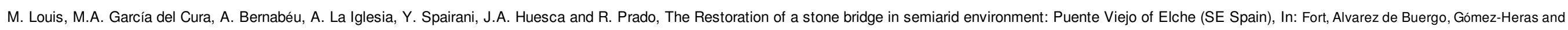
Vazquez Cal, (Eds.), Heritage, Weathering \& Conservation vol. 2, 2006, Taylor \& Francis Group; London, 881-885, Balkema.

[2]

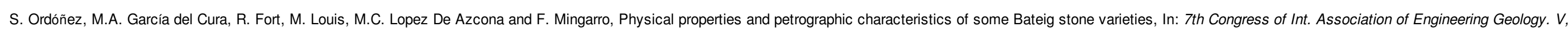
1994, 3595-3603.

[3]

J.F. Nicolas, N. Galindo, E. Yubero, C. Pastor, R. Esclapez and J. Crespo, Aerosol inorganic ions in a semiarid region on the southeastern Spanish Mediterranean COSAT, Water Air Soil Pollut. 201, 2009, 149-159.

[4]

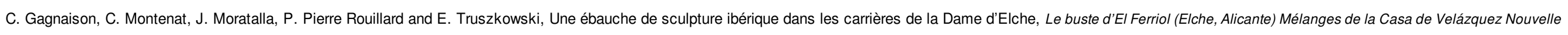
série 36 (1), 2006, 153-172.

[5]

M.P. Luxan, J.L. Prada and J. Borrego, Dama de Elche: pigments, surface coating and stone of the sculpture, Mater. Struct. 38, 2005, 419-424.

[6]

B Fitzner and K Heinrichs, Photo Atlas of Weathering Forms on Stone Monuments, 2004, http://www.stone.rwth-aachen.de (14/04/2015).

[7]

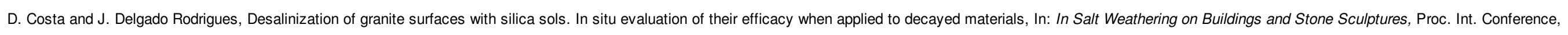
Copenhagen, 20082008, Technical University of Denmark, 317-327.

[8]

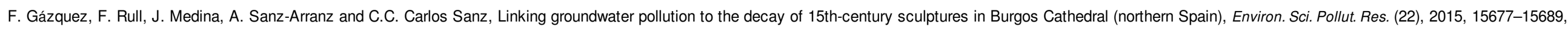
http://dx.doi.org/10.1007/s11356-015-4754-6. 


\section{elsevier_JCBM_7851}

[9]

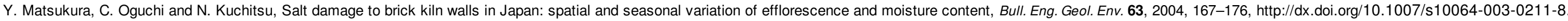

[10]

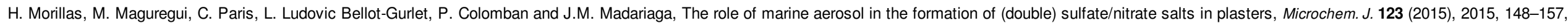
http://dx.doi.org/10.1016/j.microc.2015.06.004\}

[11]

K. Zehnder and A. Arnold, Crystal growth in salt efflorescence, J. Cryst. Growth 97 (2), 1989, 513-521, http://dx.doi.org/10.1016/0022-0248(89)90234-0.

[12]

M Steiger and A.E. Charola, Weathering and Deterioration, 227-316, In: S Siegesmund and R. Snethlage, (Eds.), Stone in Architecture Properties, Durability, 2011, Springer-Verlag; Berlin Heidelberg, 551 p.

[13]

A.E. Charola and C. Bläuer, Salts in masonry: an overview of the problem, Restorat. Build. Monuments 21 (4-6), 2015, 119-135.

[14]

G.E. Ericksen and M.E. Mrose, Mineralogical studies of the nitrate deposits of Chile. II. Darapskite, Na3(NO3)(SO4)·H2O, Am. Mineralogist 55, 1970, $1500-1517$.

[15]

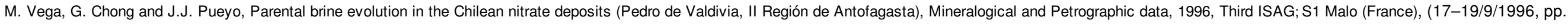
707-710)

[16]

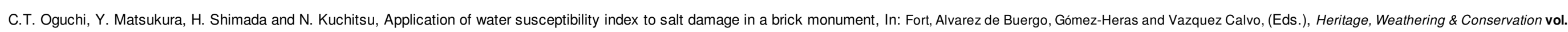
2, 2006, Taylor \& Francis Group; London, 881-885, (Balkema 217-227).

[17]

A. Shayan and C.J. Lancucki, Konyaite in salt efflorescence from a Tertiary marine deposit near Geelong, Victoria, Australia, Soil Sci. Soc. Am. J. 48, 1984, 939-942.

[18]

C.K. Kohut and M.J. Dudas, Evaporite mineralogy and trace-element, Can. J. Soil Sci. 73, 1993, 399-409.

[19]

B.J. Buck, J. King and V. Etyemezian, Effects of salt mineralogy on dust emissions, Salton Sea, California, Soil Sci. Soc. Am. J. 75, 2011, 1971-1985.

[20]

H.S. Washington and H.E. Merwin, Aphthitalite from Kilauea, Am. Mineral. 6, 1921, 121-125.

[21]

V.R.K.S. Susarla, K.M. Chudasama, V.P. Mohandas and P.K. Ghost, Glaserite preparation by sodium sulfate and potassium chloride, J. Sci. Ind. Res. 66, 2007, 444-449.

[22]

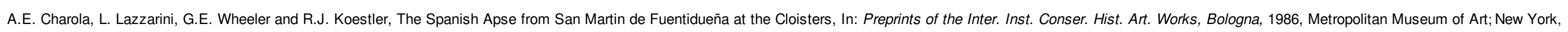
$18-21$. 


\section{elsevier_JCBM_7851}

M.E. Mrose, J.J. Fahey and G.E. Ericksen, Mineralogical studies of the nitrate deposits of Chile. III. Humberstonite, K3Na7Mg2(SO4)6(NO3)2·6H2O, a new saline mineral, Am. Mineral. 55, 1970, 1518-1533.

\section{[24]}

K. Cai, J. Gao, D. Dejun Zhao and Y. Yu, Mineralogical studies of humberstonite and darapskite in Luobubo region, China, Acta Mineral. Sin. 12 (2), $1992,143-151$.

[25]

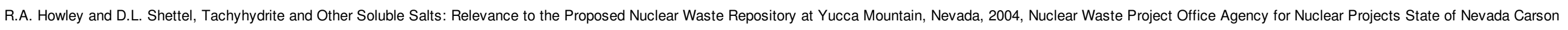
City, $30 \mathrm{p}$.

[26]

J.J. Pueyo, G. Chong and M. Vega, In: Mineralogía y evolución de las salmueras madres en el yacimiento de nitratos Pedro de Valdivia vol. 25, 1998, Revista Geológica de Chile; Antofagasta, Chile, 3-15.

[27]

G.E. Ericksen, Geology and origin of the Chilean nitrate deposits: USGS Professional Paper 1188, 1981, 37p..

[28]

G.E. Ericksen, The Chilean nitrate deposits, Am. Sci. 71, 1983, 366-374.

[29]

Y.Z. Chen, C.L. Liu, P.C. Jiao and J.M. Han, Preliminary Researches on Nitrate Formation by Metal-Catalyst Photochemical Reaction in Arid Region of Xinjiang; Mineral Deposits; 2009-05,

2009, http://en.cnki.com.cn/Article_en/CJFDTOTAL-KCDZ200905018.htm.

[30]

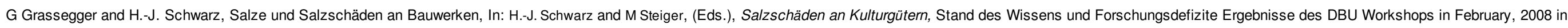
Osnabrück2008, 6-21.

[31]

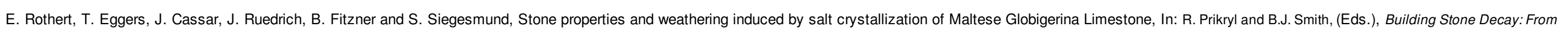
Diagnosis to Conservation 271, 2007, Geological Society, London, Special Publications, 189-198.

[32]

K. Linnow, M. Steiger, C. Lemster, H. Clercq and M. De Jovanović, In situ Raman observation of the crystallization in $\mathrm{NaNO}_{3}-\mathrm{Na}_{2} \mathrm{SO}_{4}-\mathrm{H}_{2} \mathrm{O}$ solution droplets, Environ. Earth Sci. 69 (5), 2012 , 1609-1620.

[33]

H.De. Clercq, M. Jovanovic, K. Linnow and M. Steiger, Performance of limestones laden with mixed salt solutions of $\mathrm{Na}_{2} \mathrm{SO}_{4}-\mathrm{NaNO}_{3}$ and $\mathrm{Na}_{2} \mathrm{SO}_{4}-\mathrm{K}_{2} \mathrm{SO}_{4}$, Environ. Earth Sci. $69,2013,1751-1761$.

[34]

N. Shahidzadeh-Bonn, F. Bertrand and D. Bonn, Damage in porous media due to salt crystallization, Phys. Rev. E 81, 2010, 066110, Published 16 June 2010.

[35]

E.M. Ruiz Agudo, Prevención del daño debido a la cristalización de sales en el Patrimonio Histórico Construido mediante el uso de inhibidores, (PhD Thesis)2007, Granada University, 351 pp..

[36]

C.M. Grossi, P. Brimblecombe, B. Menéndez, D. Benavente, I. Harris and M. Déqué, Climatology of salt transitions and implications for stone weathering, Sci. Total Environ. 409, 2011, $2577-2585$.

[37]

R.M. Espinosa, L. Franke and G. Deckelmann, Phase changes of salts in porous materials: crystallization, hydration and deliquescence, Constr. Build. Mater. 22, 2008, 1758-1773. 


\section{elsevier_JCBM_7851}

[38]

A.E. Charola and Herodotus, Salts in the deterioration of porous materials: an overview, JAIC 39 (3), 2000, 327-343.

[39]

O. Ozdemir, S. Karakashev, V. Anh, A.V. Nguyen and J.D. Miller, Adsorption and surface tension analysis of concentrated alkali halide brine solutions, Miner. Eng. 22, $2009,263-271$.

[40]

P. Leroy, A. Lassin, M. Azaroual and L. Andre, Predicting the surface tension of aqueous 1:1 electrolyte solutions at high salinity, Geochim. Cosmochim. Acta 74 (19), $2010,5427-5442$.

[41]

D.A.L. Leelamanie and J. Karube, Soil-water contact angle as affected by the aqueous electrolyte concentration, Soil Sci. Plant Nutr. 59, 2013, 501-508.

[42]

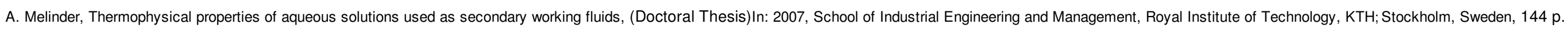

[43]

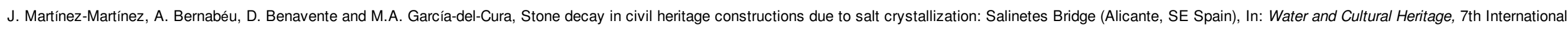

Symposium on the Conservation of Monuments in the Mediterranean Basin. June 6-9 Orleans. 2007vol. 1, 2007, 278-286.

[44]

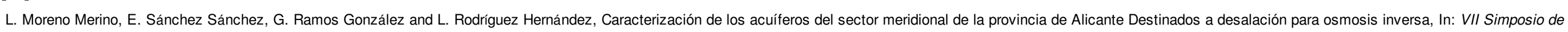
Hidrogeología, 2001, Asociación Española de Hidrología Subterránea; Murcia, 453-466, http://aguas.igme.es/igme/publica/sim_hidro_murcia.htm (12/05/2015).

[45]

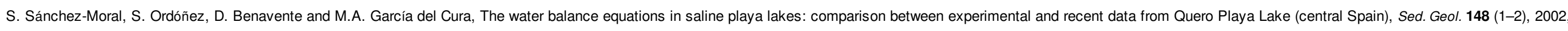
221-234.

[46]

P. Gamazo, S.A. Bea, M.W. Saaltink, J. Carrera and C. Ayora, Modeling the interaction between evaporation and chemical composition in a natural saline system, J. Hydrol. 401, $2011,154-164$.

\section{[47]}

C.W. Franzen and P.W. Mirwald, Moisture sorption behavior of salt mixtures in porous stone, Chem. Erde 69, 2009, 91-98.

[48]

Aqueous Solutions Aps (2015) The NaNO3-Na2SO4-H2O system. EXTENDED UNIQUAD http://www.phasediagram.dk/ternary/ternary1.htm (12/05/15).

[49]

Ministerio de Medio Ambiente, Programa Agua. Seguimiento del Plan Hidrológico de Cuenca del Júcar. Documento de Síntesis, 2007, Oficina de Planificación Hidrológica, 138 p.

[50]

A. La Iglesia, M. Louis, A. Bernabéu and M.A. García del Cura, Eflorescencias salinas en monumentos en clima semiárido: el Caso del Puente Viejo de Elche (Alicante), Macla 3, $2005,115-116$.

[51]

J.R. Philip, Adsorption and capillary condensation on rough surfaces, J. Phys. Chem. 62 (12), 1978, 1371-1385. 


\section{elsevier_JCBM_7851}

Y. Tardy and D. Nahon, Geochemistry of laterites, stability of Al-goethite, Al-hematite, and $\mathrm{F}^{+3}$-kaolinite in bauxites: and approach to the mechanism of concretion formation, Am. J. Sci. 285, 1985, 865-903.

\section{[53]}

S. Ordóñez, Petrofísica: aspectos generales, In: F. Mingarro, (Ed), Degradación Y Conservación Del Patrimonio Arquitectónico, 1996, 193-212.

\section{[54]}

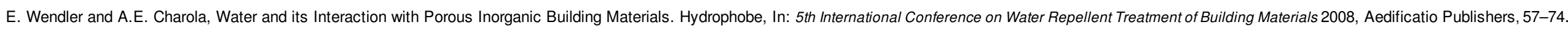

\section{[55]}

J. Coupland, An Introduction to the Physical Chemistry of Food, 2014, Springer, 182 pp.

[56]

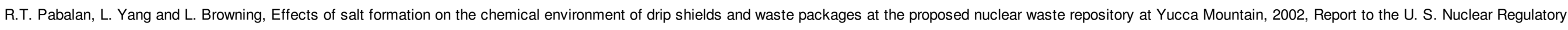
Commission, CNWRA 2002-3; Nevada, $38 \mathrm{p}$.

[57]

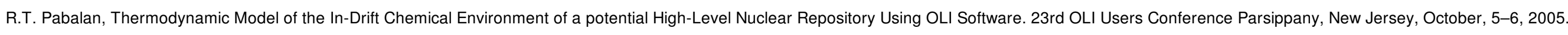

\section{[58]} Anonymous, In-Drift Precipitates/Salts Model ANL-EBS-MD-000045 REV 03 March 2007, http://pbadupws.nrc.gov/docs/ML0907/ML090770166.pdf (4/01/2016), 2007.

[59]

A.T.M Golam Mostafa, J.M. Eakman and S.L. Yarbro, Prediction of standard heats and Gibbs free energies of formation of solid inorganic salts from group contributions, Ind. Eng. Chem. Res. 34, 1995, 4577-4582.

[60]

D.D. Wagman, W.H. Evans, V.B. Parker, R.H. Schumm, I. Halow, S.M. Bailey, K.L. Churney and R.L. Nuttall, The NBS tables of chemical thermodynamic properties, J. Phys. Chem. Ref. Data. 11, 1982, 1-390.

[61]

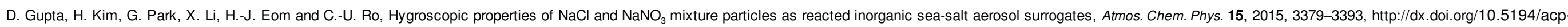
15-3379-2015, www.atmos-chem-phys.net/15/3379/2015/.

[62]

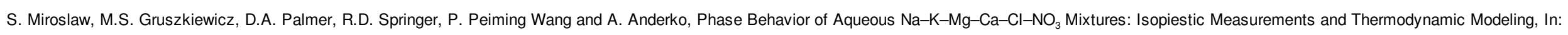
2015, http://www.osti.gov/scitech/servlets/purl/899269 (4/01/2016)

Highlights

- The efflorescence mineralogy showed a vertical distribution and changes over time.

- The mineral distribution is from interaction of RH diurnal changes and capillary flow.

- Over nine years the efflorescence developed after the intervention had reached the pre-intervention composition.

- Also simple salts, we found humberstonite, darapskite, konyaite and aphthitalite.

- Saline ions came mainly from groundwater and airborne particles. 


\section{elsevier_JCBM_7851}

\section{Queries and Answers}

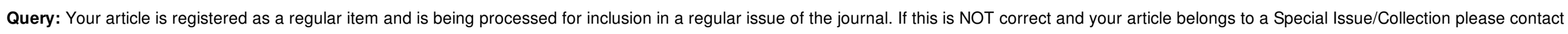
c.samiullah@elsevier.com immediately prior to returning your corrections.

Answer: It not belong to a special collection.

Query: The author names have been tagged as given names and surnames (surnames are highlighted in teal color). Please confirm if they have been identified correctly.

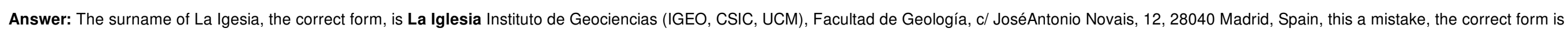
Instituto de Geociencias IGEO (CSIC, UCM), Facultad de Geología, c/ JoséAntonio Novais, 12, 28040 Madrid, Spain

Query: Please check the address for the corresponding author that has been added here, and correct if necessary.

Answer: It is ok.

Query: Please note that Fig. 3, Tables 5 and 7 were not cited in the text. Please check that the citations are in the appropriate place, and correct if necessary.

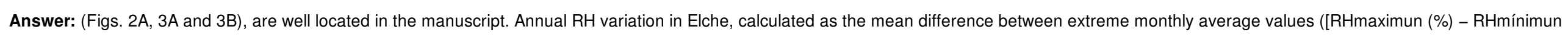

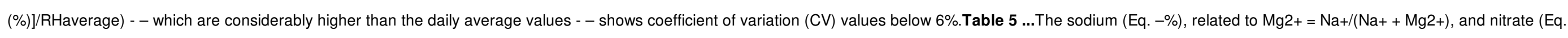

-\%) related to SO42- = $\Sigma \mathrm{N} /(\Sigma \mathrm{N}+\mathrm{S})$ was calculated from data obtained by Nicolas et al. [3], and provided an explanation for the presence of nitrates in the efflorescence. Table 7

Query: The opening quote does not have a corresponding closing quote in the sentence 'The MDRH is .... Please insert the quote in the appropriate position.

Answer: "The MDRH is always lower than the DRH of any single salt in the mixture"

Query: A mismatch between the author name and corresponding reference number in the sentence "The humberstonite would be...". Please check and correct if necessary.

Answer: Vega et al. [15]

Query: As Refs. [57] and [61] were identical, the latter has been removed from the reference list and subsequent references have been renumbered.

Answer: OK. Thank you. 